\title{
BMJ Global Health What explains the lacklustre response to Zika in Brazil? Exploring institutional, economic and health system context
}

\author{
Eduardo J Gómez, ${ }^{1}$ Fernanda Aguilar Perez, ${ }^{2}$ Deisy Ventura ${ }^{3}$
}

To cite: Gómez EJ, Perez FA, Ventura D. What explains the lacklustre response to Zika in Brazil? Exploring institutional, economic and health system context. BMJ Glob Health 2018;3:e000862. doi:10.1136/ bmjgh-2018-000862

Handling editor Alberto L Garcia-Basteiro

Received 17 April 2018 Revised 26 August 2018 Accepted 27 August 2018
D Check for updates

(c) Author(s) (or their employer(s)) 2018. Re-use permitted under CC BY-NC. No commercial re-use. See rights and permissions. Published by BMJ.

${ }^{1}$ Department of International Development, King's College London, London, UK ${ }^{2}$ Institute for International Relations, University of Sao Paulo, Sao Paulo, Brazil ${ }^{3}$ School of Public Health, University of Sao Paulo, Brazil

Correspondence to Dr Eduardo J Gómez; eduardo.gomez@kcl.ac.uk

\section{ABSTRACT}

By early-2016, the international community began to pressure Brazil for a stronger policy response to Zika. In contrast to what was seen in the past, however, these international pressures did not elicit such a response. In this article, we explore why this was the case, reviewing the government's policy response and the broader political and economic context shaping this response. The authors used single case study analysis and qualitative sources, such as books, journal articles, and government policy reports to support their empirical claims. We found that despite increased international pressures from the WHO, domestic political factors and economic recession hampered the government's ability to strengthen its health systems response to Zika. Consequently, those states most afflicted by Zika have seen policy initiatives that lack sufficient funding, administrative and human resource capacity. This study revealed that despite a government's deep foreign policy history of positively responding to international pressures through a stronger policy response to health epidemics, a sudden change in government, rising political instability, and economic recession can motivate governments to abandon this foreign policy tradition and undermine its response to new public health threats.

\section{INTRODUCTION}

By late 2015, Brazil noticed a sharp increase in the number of babies born with microcephaly and other neurological disorders in the northeastern area of the country. From 2000 to 2014, 2464 cases of microcephaly were registered in the Brazilian Information System on Live Births (Sinasc). In the year of 2015 alone, 1608 cases were registered in the whole country, with the northeastern region concentrating most of the cases (1142 in 2015, a considerable increase if compared with 2014, when 45 cases were notified in this region). ${ }^{1}$ These occurrences raised concerns to a possible connection between the Zika virus and associated neurological conditions. In response, in February 2016, the WHO declared that these brain abnormalities were a Public Health Emergency
Summary box

The Zika epidemic emerged throughout Brazil and mainly affected the poorest northeast region.

- The government's universal healthcare system Sístema Único de Saúde (SUS), has not provided adequate financial and technical support to the regions most afflicted.

- A sudden shift in government, and worsening political and economic conditions, can undermine years of government commitment to working with international health agencies.

- These challenging political and economic conditions have contributed to a reduction in SUS funding, consequently contributing to poor quality of care for women and newborns afflicted with Zika.

- Brazil needs to rejuvenate its national political commitment to strengthening SUS's primary care support for patients with Zika while also working more closely with the WHO and other international health agencies to ensure adequate financial and technical assistance in the poorest regions of the country.

of International Concern (PHEIC) while emphasising the possible connection between Zika and Guillain-Barré syndrome.

The goal of this article is to question what has happened in Brazil since the PHEIC was announced and to describe what the Ministry of Health $(\mathrm{MoH})$ and the Sístema Único de Saúde (SUS) have done in response. Our findings suggest that despite increased international pressures on Brazil for a stronger policy response, a previous lack of funding for strengthening SUS and improving healthcare facilities hampered the government's policy response. Additional funding is needed in order to ensure that SUS safeguards the most vulnerable population.

In essence, we argue that the ongoing political and economic crisis has compromised the government's response to Zika. In a country internationally praised for its normative commitment to universal healthcare, we found that the government has 
partially done its part to help fund SUS properly and to ensure an effective response to Zika.

\section{CONTEXT AND GOVERNMENT RESPONSE}

The WHO's PHEIC cannot be understood without taking into account the Olympic and Paralympic Games in Rio de Janeiro in August and September 2016 and the international community's improved understanding of Zika's public health consequences. PHEIC is defined in the International Health Regulations (IHR) (2005) as 'an extraordinary event which is determined to constitute a public health risk to other States through the international spread of disease and to potentially require a coordinated international response'. ${ }^{2}$ As the WHO claims, this definition implies a situation that is serious, sudden, unusual or unexpected; it carries implications for public health beyond the affected State's national border and may require immediate international action. ${ }^{3}$ Thus, it is unlikely that the WHO would have issued the PHEIC in response to Zika had it not been for the virus' emergence amidst heightened world attention to the Olympic games.

Margaret Chan, WHO General Director at that time, came to Brazil on February 2016, shortly after the PHEIC was announced, to oversee the Brazilian response to Zika. ${ }^{4}$ Chan stated that the games would take place during the Brazilian winter, which translated to an expected low mosquito density due to drier climate. Nevertheless, the WHO's position through the PHEIC was challenged when in late May 2016, international health experts called for the Olympics in Rio to be postponed because of Zika. ${ }^{5}$ Nevertheless, the WHO did not change its stance. ${ }^{6}$ On July 2016, a WHO specialists committee declared that 'there is a very low risk of further international spread of Zika as a result of the Olympic and Paralympic Games, and (Brazil) is intensifying vector-control measures in and around the venues for the Games which should further reduce the risk of transmission' ${ }^{7}$ It appears that the WHO endeavoured to quickly respond to Zika and to pressure Brazil for a strong policy response.

\section{Government response}

From November 2015 to December 2016, 10232 cases of microcephaly were notified to the $\mathrm{MoH}$, with 2205 cases confirmed to be microcephaly. ${ }^{8}$ Until March 2017, the $\mathrm{MoH}$ received 3536 notifications for microcephaly, of which 211 were confirmed. ${ }^{9}$ The MoH developed a policy strategy emphasising three major pillars: vector control (Aedes aegypti), assurance of access to healthcare to people with Zika-related neurological conditions and technology and research development. ${ }^{10}$

\section{Vector control}

Zika's vector, $A$. aegypti, has for a very long time been an issue in Brazil: in 1955, the country took part in an international programme to eradicate the vector. Fully adapted to the urban environment and infesting $70 \%$ of Brazilian municipalities, $A$. aegypti is also responsible for transmitting yellow fever, dengue haemorrhagic fever and chikungunya, and recent epidemic outbreaks of these diseases have also been recorded. ${ }^{11}$

During the Zika crisis, actions such as house inspections, to find possible A. aegypti larvae or breeding grounds were intensified by the $\mathrm{MOH}$, while freely providing mosquito repellent cream to pregnant women living in impoverish conditions. On 11 March 2016, a government provisional measure was issued, ${ }^{12}$ allotting R $\$ 70$ million to the Armed Forces so that they could help eradicate mosquitos, and $\mathrm{R} \$ 300$ million to the $\mathrm{MoH}$ for the purchase of materials and equipment for the protection of pregnant women registered in the Brazilian social welfare programme, known as Bolsa Família.

In April 2016, a federal decree was issued, establishing the 'Programme for prevention and individual protection of pregnant women on vulnerable socioeconomic situations against the Aedes aegypti. ${ }^{13}$ Moreover, on 21 November 2016, the government issued an auction notice with the terms of the public bidding for the acquisition of mosquito repellent cream for pregnant women. ${ }^{14}$ On December 9 the auction bid ended, with a predicted cost of $\mathrm{R} \$ 82$ million. ${ }^{15}$ With this money, the government planned to protect 500 thousand pregnant women registered with the Bolsa Familia programme. ${ }^{16}$ However, 2 months later, the Brazilian Federal Court of Accounts issued a judgement ordering the $\mathrm{MoH}$ to test in a laboratory the efficacy of the cream, since the Courts had doubts of active substance concentration in the solution, potentially putting at risk the lives of thousands of pregnant women. ${ }^{17}$

\section{Access to healthcare}

Regarding those infants affected by microcephaly and their access to healthcare, the situation is not clear. Even though the government developed guidelines to ensure infants would receive proper healthcare, ${ }^{18}$ the information so far made available by the administration does not permit an in-depth analysis of what these families are actually receiving. According to the $\mathrm{MoH}$, of the 2621 confirmed cases of microcephaly, 1369 (52,2\%) received child care, $1110(42,4 \%)$ early stimulation and $1507(57,5 \%)$ specialised care. ${ }^{19}$ However, these numbers only represent infants who got referred and had an appointment. Other variables to indicate details such as continuity of treatment, number and frequency of consultations and the number of healthcare professionals involved, for instance, are not available.

The Zika epidemic struck one of the poorest areas of Brazil, the northeastern area. Furthermore, the distribution of healthcare capacity in Brazil is unequal. In these most affected areas, there are less doctors per 1000 people than the national average and less public clinics appointments per year than the national average. The concentration of healthcare professionals in the southeastern region is considered to be caused 
by better access to infrastructure and better training opportunities. For all of the northeastern states, SUS represents the main healthcare available. ${ }^{20}$

Nonetheless, some changes have taken place. Additional Centres Specialized in Rehabilitation (Centros Especializados em Reabilitação (CERs)) were created to provide treatment to Zika-affected children. Originally established to deliver particular care to people with disabilities, the CERs were authorised to look after children with microcephaly. In March 2017, Brazil had 187 CERs (52 were inaugurated in 2016), with an annual cost of $\mathrm{R} \$ 114.3$ million. The government promised to construct more CER units and also allotted $\mathrm{R} \$ 10.9$ million to establish more Family Health Programme teams. $^{21}$

The government's policy response to Zika was criticised by Brazilian legal institutions. The National Association of Public Defenders (ANADEP), a body representing Brazilian Public Defenders, filed a Direct Action of Unconstitutionality in the country's Supreme Federal Court (SFC; the government's highest legal authority). This legal instrument is used to declare if a law is disrespecting the Federal Constitution, and the National Association used this instrument to question norms issued by the government after the Zika outbreak.

To ANADEP, the norms were an inadequate way of 'responding to an outbreak of considerable magnitude, with catastrophic consequences to the population's health. First, because many public policies of wide access to health and social security do not reach the poor, they are most at risk of acquiring Zika. And second, because actions are planned without any budgetary allocation for their execution'. ${ }^{22}$

Furthermore, the Prosecutor General of the Republic (PGR), head of the Brazilian Federal Prosecution Service, asked the SFC to declare the unconstitutionality of an excerpt of a law permitting the dispersal of chemical substances by aircrafts as an A. aegypti containment measure. ${ }^{23}$ To the PGR, this endeavour is inconsistent with constitutional precepts, and the efficacy of the dispersion of chemical substances by air to reduce vector breeding was perceived as dubious. ${ }^{24}$

What is even more puzzling is the amount of federal funding the $\mathrm{MOH}$ received to deal with Zika. Although the government highlighted how much funding the CERs would receive, the precise amount of how much federal funding SUS would receive is unclear. Even a well-known government document titled the 'Response to Zika Virus strategy and combat to the vector', emphasised that the government needed to provide a clear budgetary estimate to deal with the virus and allocate resources according to each area and sphere of government requirements. However, the report went on to state that no amount of money is specified. ${ }^{25}$

\section{Technology and research development}

Research development was also an important aspect of the Brazilian response to Zika. The already mentioned provisional measure issued in March 2016 allotted $\mathrm{R} \$ 50$ million for research ${ }^{26}$ and in April the government decided to invest $\mathrm{R} \$ 10$ million for the establishment of a national biobank of samples of saliva, blood and urine, so that research about diseases whose vector is the $A$. aegypti can be further developed. ${ }^{27}$ Initiatives like this continued, and in July 2016, the government publicly announced that $\mathrm{R} \$ 65$ million would be available for research analysing prevention, diagnose and Zika treatment. ${ }^{28}$

All of these resources available for this third pillar of the Brazilian response might conceal the absence of intense research on communicable diseases and on vector control methods in the past. As Pimenta and Nunes ${ }^{29}$ discuss, there are many neglected matters surrounding the Zika incident, and 'flaws in funding and in research end up affecting disproportionally vulnerable populations in risk (sic) situations'.

All three pillars of the aforementioned policy strategy share one common feature: their planning and development are fragmented and diluted. Efforts for vector control, improvements in access to healthcare delivery and research funding cannot be boosted with random actions and sporadic resources; they require a clear project, sufficient provision of resources and schedules. Even though the microcephaly epidemic was an unexpected outcome, A. aegypti is not an unknown mosquito in Brazil. The country faced several dengue haemorrhagic fever outbreaks in recent years, which means that efforts for vector control should not demand extra budgetary resources; it should already be a part of the MoH agenda.

Moreover, the main strategy should be to combat the vector, curbing the breeding of the $A$. aegypti. In a country where 7 million houses do not have access to rubbish and waste collection, and where 10 million do not have access to clean and chlorinated water in their households, ${ }^{10}$ application of mosquito repellent twice a day will not be effective in the long term.

Furthermore, had SUS been strengthened in recent years, the system would now be able to quickly deliver proper care to these affected families. Yet, the country decided to go the opposite direction and cut SUS' budget for 2016, after changing the way investments in the system would be calculated. ${ }^{30}$ Many public health associations, including the Federal Council of Medicine, expressed their position against a change in the budget, which will translate to losses of up to $\mathrm{R} \$ 10$ billion for SUS, weakening the health system in all its aspects: surveillance, prevention and care delivery. ${ }^{30}$

There was nevertheless a sharp increase to the $\mathrm{MoH}$ authorised overall budget between the years 2010 and 2015 , increasing from $R \$ 69.70$ billion in 2012 to $R \$ 121.10$ billion in 2015 (values in the current exchange rate to US \$ would be from 21 billion to 37 billion, respectively). However, from 2015 onwards, the amount of money available presented only a slight increase, reaching $R \$ 125.70$ billion for the year 2017 (around US\$39 billion). ${ }^{31}$ From 
2015 to 2017, the authorised MoH budget essentially flatlined.

During this period, Brazil also experienced an economic recession, with gross domestic product decreasing from $3.8 \%$ in 2015 to $3.6 \%$ in $2016 .{ }^{32}$ Vieira et $a l^{33}$ claims that because of the severe economic recession of 2015/2016, the government's tax collection and revenues sharply decreased, negatively affecting healthcare financing. ${ }^{33}$

\section{POLITICAL INTERFERENCE AND POLICY CONSEQUENCES}

Why did the government fail to strengthen its health system's response to Zika? What is troubling is that this occurred even in a context of increased WHO pressures for a strong policy response through the aforementioned PHEIC. We argue that Brazil's lacklustre response was shaped by policy decisions and challenges that arose before Zika emerged.

Indeed, beginning under the Lula administration, at a time when the government was fully committed to antipoverty and human development issues, there was no effort to substantially improve SUS and its funding mechanisms. In fact, SUS had been underfunded for several years, a direct consequence of several failed policy initiatives and lack of clarity in how federal and state resources would be managed. ${ }^{34}$

Recent studies even pointed out that, as early as 2010 , Brazil was underestimating the prevalence rate of microcephaly at birth, presenting more cases than the world average. Potential causes include 'variables closely linked to poverty', such as 'low maternal schooling' or not having a companion. ${ }^{35}$ However, prevalence during Zika crisis are indeed higher and cases are much more severe. 3637

The government's focus at the time was on partially addressing the social determinants of health, and the dominant view was that alleviating poverty and hunger would contribute to good health, well-being and economic productivity. The focus was not on helping the states fund basic healthcare infrastructure and human resources, a responsibility that was increasingly assigned to the states and municipalities. ${ }^{38}$

Presidents Dilma and Temer's ascendance into the presidency did not improve the situation. Dilma essentially adopted Lula's antipoverty platform. Her priority since assuming office in 2010 was to eradicate poverty and rejuvenate the economy. Dilma voiced concern for improving SUS, as evident through the creation of the Mais Médicos (More Doctors) programme, which provided additional doctors and distributed them throughout the country. ${ }^{39}$ However, corruption scandals and political turbulence shifted the government's policy focus away from increasing federal funding for social policies towards instead rejuvenating political confidence. Zika emerged in the middle of this conundrum. Aside from supporting the Armed Force's involvement in helping vector inspection in households in highly infected areas, federal funding to support hospitals in these areas was deemed insufficient even before the county was hit by the Zika outbreak. ${ }^{40}$

Moreover, Dilma's impeachment in 2015 and the arrival of Michel Temer as her replacement did not lead to an increase in federal funding for SUS and improvements to care delivery. Instead, his focus was on adopting neoliberal policies, which entailed decreasing spending for the $\mathrm{MoH}$, regardless if society's needs were not met. ${ }^{41}$ Temer's neoliberal views have contributed to a decline in federal financial support for SUS (Reis $e t a l),{ }^{42}$ further hampering SUS' ability to respond to Zika. ${ }^{41}$

\section{CONCLUSION}

The case of Brazil's response to Zika highlights important lessons and concerns. Political instability can overcome years of progress in positively responding to international pressures for a stronger policy response to public health threats. Furthermore, the government seems to have abandoned its foreign policy strategy of using an improved domestic policy response to disease as a way to bolster and sustain Brazil's international reputation for being a responsive state, adhering to its constitutionally enshrined human rights principles of guaranteeing access to healthcare while providing technical assistance to other nations. ${ }^{36}$

Although the Brazilian response to Zika is often criticised, it is undeniable that this response would be much more difficult, perhaps even impossible, without SUS. The detection of the link between Zika and microcephaly itself was only possible thanks to the hard work of SUS doctors and SUS disease surveillance system. ${ }^{43}$ Neither would epidemiological case notifications and enforcement of a national response exist without this immense public health system, whose reach includes a portion of the population that would not have access to healthcare if the system was private.

The case of Brazil also suggests that in order to amass a successful response to Zika and other public health threats, the central government must be fully committed to providing funding and technical assistance to resource poor areas. Indeed, had the government-funded SUS properly throughout these years and had the $\mathrm{MoH}$ developed programmes focused on reducing people's vulnerability to communicable diseases before the emergence of a new viral outbreak, perhaps the consequences of Zika would have been different. Going forward, Brazil's $\mathrm{MoH}$ must find innovative ways to ensure that local hospitals and primary healthcare centres receive the funding and human resources needed to treat children and provide family assistance and deliver proper healthcare to vulnerable populations, mainly woman living in poor conditions.

Regarding the three policy pillars developed by the government as part of its Zika strategy response, all of them entailed problems and potential solutions. Vector control is necessary, but as Ventura ${ }^{44}$ explains, it is an immediate measure and should be undertaken in combination with other initiatives, such as an increase in federal funding for supportive social programme. Once the emergency has 
subsided, only an efficient healthcare system can guarantee continuity of care for persons affected by the crisis'.

Going forward, the government will need to ensure that it finds innovative ways to assist local governments and that it positively responds to and works closely with the international community. This will be important for maintaining the government's commitment to international cooperation and effectively treating women and children.

Contributors EJ and FAP were the main authors of this study. FAP conducted most of the empirical analysis and data collection in Brazil, while EJ contributed to the political and institutional aspects. DV contributed to the section on Brazil's relationship with the international community. EJ and FAP were mainly responsible for organising the overall structure of the article and coauthoring the sections.

Funding The authors have not declared a specific grant for this research from any funding agency in the public, commercial or not-for-profit sectors.

Competing interests None declared.

Patient consent Not required.

Provenance and peer review Not commissioned; externally peer reviewed.

Data statement No additional data are available.

Open access This is an open access article distributed in accordance with the Creative Commons Attribution Non Commercial (CC BY-NC 4.0) license, which permits others to distribute, remix, adapt, build upon this work non-commercially, and license their derivative works on different terms, provided the original work is properly cited, appropriate credit is given, any changes made indicated, and the use is non-commercial. See: http://creativecommons.org/licenses/by-nc/4.0/

\section{REFERENCES}

1. Marinho F, Araújo VE, Porto DL, et al. Microcephaly in Brazil: prevalence and characterization of cases from the Information System on Live Births (Sinasc), 2000-2015. Epidemiol Serv Saude 2016;25:701-12.

2. WHO. International health regulations. 3rd edn. Geneva: WHO, 2005.

3. WHO, 2016. International health regulations and emergency committees. http://www.who.int/features/qa/emergencycommittees/en/ (accessed Feb 2018).

4. WHO, 2016. Zika response accelerates as WHO Director-General visits Brazil. http://www.who.int/features/2016/zika-brazil/en/ (accessed Feb 2018).

5. The Guardian, 2016. WHO rejects call to move Rio Olympics because of Zika virus. https://www.theguardian.com/world/2016/ may/27/who-urged-to-consider-moving-rio-olympics-due-to-zikaoutbreak (accessed Feb 2018).

6. Chade J, 2016. Não existe justificativa para adiar os Jogos Olímpicos - diz OMS, Estado de S. Paulo. http://esportes.estadao. com.br/noticias/jogos-olimpicos,nao-existe-justificativa-para-adiarrio2016-diz-oms,10000053856 (accessed Feb 2018).

7. WHO statement on the third meeting of the International Health Regulations, 2016. (IHR(2005) Emergency Committee on Zika virus and observed increase in neurological disorders and neonatal malformations. http://www.who.int/mediacentre/news/statements/ 2016/zika-third-ec/en/ (accessed Feb 2018).

8. Brazilian Ministry of Health - Department of Health Surveillance. Boletim Epidemiológico. 48, 2017.

9. Brazilian Ministry of Health - Department of Health Surveillance. Boletim Epidemiológico, 2017.

10. Henriques CMP, Duarte E, Garcia LP. Editorial: desafios para o enfrentamento da epidemiologia de microcefalia. Epidemiol. Serv. Saúde 2016;25:7-10.

11. Braga IM, Valle D. Aedes aegypti: histórico do controle no Brasil. Epidemiol Serv Saude 2007;16:113-8.

12. Presidency of the Republic of Brazil - Casa Civil. Provisional measure $n^{\circ}$ 716, 11th March 2016 abre crédito extraordinário, em favor dos Ministérios da Ciência, Tecnologia e Inovação, da Defesa e do Desenvolvimento Social e Combate Fome, no valor de $R \$ 420.000 .000,00$, para os fins que especifica. The Provisional Measure became domestic Law $n^{\circ} 13310,2013$.

13. Presidency of the Republic of Brazil - Casa Civil. Provisional Measure $n^{\circ} 71$, Abrecrédito extraordinário, em favor dos Ministérios da Ciência, Tecnologia e Inovação, da Defesa e doDesenvolvimento Social e Combate Fome, no valor de $R \$ 420.000 .000,00$, para os fins que especifica. The Provisional Measure became domestic Law $n^{\circ} 13310$ on July 7th 2013, 2016.

14. Federal Official Gazette of Brazil. Aviso de Licitação - Pregão Eletrônico $n^{\circ}$ 58/2016 - UASG 25005. N²22, 2016.

15. Portal Brasil, 2016. The Ministry of Health estimated on the auction notice a total cost of $\mathrm{R} \$ 208,8$ million for the purchase of the repellent creams, but the winner offered a price circa $60 \%$ lower than expected by the government. Governo seleciona fornecedor de repelentes que serão distribuídos a grávidas. http://www. brasil.gov.br/saude/2016/12/governo-seleciona-fornecedor-derepelentes-que-serao-distribuidos-a-gravidas (accessed Feb 2018).

16. Brazilian Ministry of Health, 2016. Ministério da Saúde finaliza pregão para compra de repelentes. Ministério da Saúde Notícias. http://combateaedes.saude.gov.br/pt/noticias/896-ministerio-dasaude-finaliza-pregao-para-compra-de-repelentes

17. Federal Official Gazette of Brazil. ACÓRD ̃̃O No 123/2017 - TCU Plenário. $N^{\circ}$ 29, p. 111, 09 de fevereiro de, 2017.

18. They were, in Portuguese, "Protocolo de atenção à saúde e resposta à ocorrência de microcefalia" and"Diretrizes de estimulação precoce para crianças de 0 a 3 anos com atraso de no desenvolvimento neuropsicomotor decorrente de microcefalia".

19. Brazilian Ministry of Health - Department of Health Surveillance. Boletim Epidemiológico. , 2017: 48, 4.

20. Nunes A, Santos JRS, Barata RB. Medindo as desigualdades em saúde no Brasil: uma proposta de monitoramento. Organização PanAmericana de Saúde e Instituto de Pesquisa Econômica Aplicada 2001;56:82

21. Brazilian Ministry of Health, 2017. Ministério da Saúde destina R\$ 135,2 milhões para reabilitação e pesquisas. http://portalsaude. saude.gov.br/index.php/o-ministerio/principal/secretarias/svs/ noticias-svs/27940-ministerio-da-saude-destina-r-135-2-milhoespara-reabilitacao-e-pesquisas (accessed Feb 2018).

22. Superior Federal Court. Ação Direta de Inconstitucionalidade 5.581 Distrito Federal. Relatora: Ministra Cármen Lúcia. Requerente: Associação Nacional dos Defensores Públicos. Decisão, 2016.

23. Brazil. Law n. 13.301, 2016. Dispõe sobre a adoção de medidas de vigilância em saúde quando verificada situação de iminente perigo saúde pública pela presença do mosquito transmissor do vírus da dengue, do vírus chikungunya e do vírus da zika; e altera a Lei no 6.437, de 20 de agosto de 1977. http://www.planalto.gov. br/ccivil 03/ ato2015-2018/2016/lei/L13301.htm (accessed Feb 2018).

24. Prosecutor General of the Republic, 2016. ADI 5592. Medidas de combate ao mosquito Aedes aegypti.Dispersão aérea de produtos químicos. https://www.abrasco.org.br/site/wp-content/uploads/ 2016/09/ADI-5592.pdf (accessed Feb 2018).

25. Presidency of the Republic of Brazil - Casa Civi. Estratégia de Resposta ao Vírus Zika e o Combate ao mosquito transmissor. Brasilia, 2016.

26. Presidency of the Republic of Brazil - Casa Civil. Provisional Measure $n^{\circ}$ 716,11th March 2016. Abre crédito extraordinário, em favor dos Ministérios da Ciência, Tecnologia e Inovação, da Defesa e do Desenvolvimento Social e Combate Fome, no valor de $R \$ 420.000 .000,00$, para os fins que especifica. The Provisional Measure became domestic Law n¹3310, 2016.

27. Presidency of the Republic of Brazil - Portal Brasil, 2017. Combate a infecções do Aedes tem reforço de R\$135 milhões. http://www. brasil.gov.br/saude/2017/04/combate-a-infeccoes-do-aedes-temreforco-de-r-135-milhoes (accessed Jan 2018).

28. Brazilian Ministry of Health, 2016. Blog da Saúde. R\$ 65 millhões para pesquisa sobre o vírus Zika. http://www.blog.saude.gov.br/ index.php/entenda-o-sus/51347-r-65-milhoes-para-pesquisassobre-o-virus-zika (accessed Feb 2018).

29. Pimenta DN, Nunes J. A Epidemia de Zika e os Limites da Saúde Global. Lua Nova 2016;9831:21-46.

30. Conselho Federal de Medicina, 2016. Nota das entidades contra o corte no orçamento do SUS. Escola Nacional de Saúde Pública Sério Arouca Fiocruz, notícias. http://www6.ensp.fiocruz.br/visa/?q= node/6990 (accessed Mar 2018).

31. Brazilian Senate. Orçamento da União. https://www12.senado. leg.br/orcamento/loa?ano=2011\&categoria=4.1.1\&fase=execucao (accessed Oct 2017).

32. IBGE. Indicadores IBGE - Contas Nacionais Trimestrais, 2016

33. Vieira FS, Sá e Benevides R. Os impactos do novo regime fiscal para o financiamento do sistema único de saúde e para efetivação do direito saúde no Brasil. Nota técnica do IPEA n²8. Brasília, 2016.

34. Mendes Áquilas, Mendes A. A longa batalha pelo financiamento do SUS. Saúde e Sociedade 2013;22:987-93. 
35. Silva AA, Barbieri MA, Alves MT, et al. Prevalence and Risk Factors for Microcephaly at Birth in Brazil in 2010. Pediatrics 2018;141:e20170589.

36. Gómez EJ. Geopolitics in health: confronting obesity, AIDS, and tuberculosis in the eme rging BRICS nations. Baltimore: Johns Hopkins University Press, 2018.

37. Melo AS, Aguiar RS, Amorim MM, et al. Congenital Zika Virus Infection: Beyond Neonatal Microcephaly. JAMA Neurol 2016;73:1407-16.

38. Mendes A. "A longa batalha pelo financiamento do SUS," Sáude e Sociedade 2013;22:991-3.

39. Campos GWS, Pereira Júnior N. Primary health care in Brazil, and the Mais Médicos Program in the Unified Health System: achievements and limits. Ciência e Saúde Coletiva 2016;21:2655-63.
40. Hennigan T. Brazil struggles to cope with Zika epidemic. BMJ 2016;352:1226.

41. Malta M. Human rights and political crisis in Brazil: public health impacts and challenges. Glob Public Health 2018:1-8.

42. Reis AACdos, Sóter APM, Furtado LAC. Tudo a temer: financiamento, relação público e privado e o futuro do SUS. Saúde em Debate 2016;40:122-35.

43. Diniz D. Zika: from the brazilian backlands to global threat. London: Zed books, 2017.

44. Ventura DF. From Ebola to Zika: international emergencies and the securitization of global health. Cad Saude Publica 2016;32:1-4. 